\title{
CONTROL OF AUTOMOBILE EMISSIONS- CALIFORNIA EXPERIENCE AND THE FEDERAL LEGISLATION
}

\author{
Harold W. Kennedy* and Martin E. WeEkes $\dagger$
}

\section{INTRODUCTION}

The cities in the East compare to the cities in the West in much the same way that mature women would compare to adolescent maidens. The cities in the East have compacted, restrained, well-positioned pockets of density; the population and industry in cities of the West seem to have the propensity to sprawl asymmetrically to occupy the greatest area with the least anatomy.

Since the population is so diversely distributed in the western states, transportation between concentrations of population and industry is not generally served through the use of rapid transit or other community transportation facilities. Furthermore, the more desirable residential areas were and are significantly distant from areas of industry. Therefore it became necessary, particularly during the Second World War, for the inhabitants of such areas as Los Angeles County to provide their own means of transportation to and from centers of commerce. The mode of transportation utilized was the automobile.

During the Second World War industrial growth in California proceeded at an astronomical rate. The great growth of industry, coupled with the unparalleled intensity of the use of the automobile as a method of transportation, brought with it mushrooming problems of air pollution.

Due to environmental conditions peculiar to the Los Angeles basin, this air pollution manifested itself in discomfort to the eyes and respiratory tract of the inhabitants. The County of Los Angeles became blanketed with a brownish haze which was given the misnomer smog. 1

For a number of years it seemed as if this phenomenon was peculiar to Los Angeles and was not really indicative of an air pollution problem which would become national, if not international, in scope. However, the experiences first felt by those in Los Angeles have occurred with ever increasing frequency in other urban areas throughout the United States. ${ }^{2}$ Greater use of the automobile and in-

- B.S. 1923, J.D. 1925, University of California at Berkeley; M.S. (Pub. Admin.) I954, University of Southern California. County Counsel Emeritus, Los Angeles County, California. Member of the Californiz bar. Contributor of articles to periodicals in the public law field.

† B.S. I954, Manhattan College; J.D. I96r, University of Southern California. Deputy County Counsel, Los Angeles County, California. Member of the California bar.

1 "Smog" is a contraction of the words "smoke" and "fog." The air pollution problem in Los Angeles County is generally conceded to be the product of oxides of nitrogen, oxides of sulfur, and photochemical reactions with hydrocarbons.

${ }^{2}$ See Air Quality Act of $1967, \$$ Ior (a), 81 Stat. 485; President of the United States, Message ox 
creased intensification of industry have brought with them burgeoning problems in air pollution.

The County of Los Angeles has for some twenty years waged an effective battle against air pollution caused by stationary sources. It is generally agreed, however, that there is still a serious problem with air pollution in Los Angeles County; and it is also agreed that the automobile is primarily responsible for the continuing problem. $^{3}$

In order to combat air pollution emanating from the automobile, California, in I960, enacted the Motor Vehicle Pollution Control Act. ${ }^{4}$ A study of the history leading to, and developments under, this act will materially benefit those attempting to inaugurate an effective control program directed at air pollution emanating from the use of the automobile.

\section{I}

\section{Attempts at Abatement Prior to the 9667 Legislation}

Prior to rg6o there had been only one California statute specifically directed at air pollution emanating from motor vehicles. It provided: "No motor vehicle shall be operated in a manner resulting in the escape of excessive smoke ... or fuel residue." The constitutionality of the section was challenged unsuccessfully on the basis that the word "excessive" was too indefinite and uncertain to satisfy the requirements of due process. ${ }^{8}$

\section{A. Duties of State Director of Public Health Under Previous Legislation}

In 1959 the California legislature provided: ${ }^{7}$

It shall be the duty of the State Director of Public Health to determine by February I, 1960, the maximum allowable standards of emissions of exhaust con-

Arr Pollurion, H.R. Doc. No. 47, 90th Cong., Ist Sess. (1967); H.R. REP. No. 728, goth Cong., Ist Sess. (1967); S. Rep. No. 403, goth Cong., Ist Sess (1967); H.R. Rep. No. 9I6, goth Cong., Ist Sess. (Conference report $\mathrm{I} 6_{7}$ ).

- See Calif. State Dep't of Public Health, California Standards for Ambient Air Quality and FOR MOTOR Vehicle EMISSIONS (I966).

'Ch. 23, § I, [I961] Cal. Stats. 346 (repealed 1967).

- Cat. Vefrcle CODE $\$ 27153$ (West I960). (Emphasis added.)

'In rejecting the contention, the district court of appeals quoted with approval from the case of Smith v. Peterson, I3I Cal. App. 2d 24I, 280 P.2d 522 (I955), which construed the "excessive noise" statute:

"[A] statute, to be valid, [is not required to] have that degree of exactness which inheres in a mathematical theorem. It is not necessary that a statute furnish detailed plans and specifications of the acts or conduct prohibited. The requirement of reasonable certainty does not preclude the use of ordinary terms to express ideas which find adequate interpretation in common usage and understanding."

People v. Madearos, 230 Cal. App. 2d 642, 644, 41 Cal. Rper. 269, 27 (1964).

${ }^{7}$ Ch. 200, \$ I, [1959] Cal. Stats. 2091 (repealed 1967). In I960 the Legislature modified this language by replacing the period at the end of the first paragraph with a comma and adding thereto "interference with visibility and damage to vegetation." The final paragraph was extended by the addition of another sentence: "In revising the standards the department shall, after February 1, 1960, take into account all emissions from motor vehicles rather than exhaust emissions only." Ch. 36, 51, [1960] Cal. Stats. 380 (repealed 1967 ). 
taminants from motor vehicles which are compatible with the preservation of the public health including the prevention of irritation to the senses.

The standards shall be developed after the department has held public hearings and afforded an opportunity for all interested persons to appear and file statements or be heard. The department shall publish such notice of the hearings as it determines to be reasonably necessary.

The department after notice and hearing may revise the standards, and shall publish the revised standards, from time to time.

In 1965 the provision was added: ${ }^{8}$

Whenever the department revises the standards it shall submit a copy of such revised standards to the Legislature if the Legislature is in session, or to the Senate Fact Finding Committee on Transportation and Public Utilities and the Assembly Interim Committee on Transportation and Commerce if the Legislature is not in session, and such revised standards shall not become effective until the 3Ist day after such submission.

Under this legislation, the State Director of Public Health developed the standards which have since been enacted into title I7, section 30500 et seq. of the California Administrative Code. The question then arose whether the Air Pollution Control Officer could cite those vehicles which did not comply with the standards set forth by the Director of Public Health on the ground that a vehicle which did not so comply would be operated in such a manner that it resulted in "the escape of excessive smoke or fuel residue." Although this specific question has never been considered by California's appellate courts, it has been answered in the negative by the Attorney General. ${ }^{9}$ Since 1963 the Vehicle Code has been amended many times, but at no time has the legislature seen fit to negate the conclusions of the Attorney General. ${ }^{10}$

${ }^{8}$ Ch. 203I, \$ I, [1965] Cal. Stats. 4607 (repealed 1967).

- "The view has been expressed that any standards adopted by the State Department of Public Health under section 426.5 would be applicable in prosecutions for excessive smoke emissions under the earlier provisions of the Vehicle Code and Health \& Safety Code set forth above. We are unable to find statutory support for this argument. Rather, it appears that the intent of the Legislature was to make the standards adopted under section 426.5 applicable solely as guides for the Motor Vehicle Pollution Control Board in its consideration of control devices. Indicative of such legislative intent is Health \& Safety Code section 24378 (c), declaring, among other findings of the Legislature, "That, as the Department of Public Health has established standards for . . . emissions of contaminants for motor vehicles pursuant to Section(s) . . 426.5, the State has a responsibility to establish uniform procedures for compliance with these standards.' The procedures referred to are the certification of control devices by the Motor Vehicle Pollution Control Board." Opinion No. 63-I 44, 42 Op. CAL. AtT'y GEN. 47, 48 (I963).

20 "While the opinions of the Attorney General are not controlling as to the meaning of the statute the fact that his opinions have not been challenged and that he is the officer charged by law with advising the officers charged with the enforcement of the law as to the meaning of it, entitle his opinions to great weight." Smith v. Municipal Court, I67 Cal. App. 2d 534, 539, 334 P.2d 931, 935 (1959).

"Moreover, since the statute upon which plaintiffs rely was reenacted and transferred to the Government Code in 1949 , as well as amended in 1951 , it may be presumed that the Legislature was cognizant of the construction which had been placed thereon by the attorney general in his 1945 and I956 opinions cited hereinabove. This is a factor which may be considered in applying the statute." Southwest Exploration Co. v. County of Orange, 44 Cal. 2d 549, 554, 283 P.2d 257, 259 (1955). 


\section{B. Duties of Motor Vehicle Pollution Control Board Under Previous Legislation}

After the Director of Public Health acted under the 1959 legislation to promulgate standards, these standards were forwarded to the Motor Vehicle Pollution Control Board. The Board was charged with the responsibility for establishing a test procedure for any devices designed to abate air pollution emanating from a particular source in the vehicle. When the Board determined that a device existed which would control the emissions emanating from a particular source in the vehicle to within the specifications established pursuant to the law, ${ }^{11}$ then the device would be certified. Installation of the device would not become mandatory until such time as two such devices were in fact certified. ${ }^{12}$

The intention of the Legislature in requiring certification of two or more devices was set forth in these terms by the Attorney General: ${ }^{13}$

It has been suggested that the purpose of the "two or more" device requirement is to insure competition between two or more companies in the manufacture of the device, thus preventing an excessive price due to monopolistic conditions. Consequently, it is argued that the licensing of a second manufacturer to produce the same device competitively should satisfy the intent of the Legislature in enacting section 24388. This argument is rejected for the following reasons:

I. Such an interpretation would not adequately conform to legislative intent. Certainly one of the purposes of the "two or more" device requirement is to prevent an excessive price to the ultimate consumer. But such a purpose would be only partially met by competition without product diversity. If the same device produced by two different manufacturers is deemed to meet the requirements of the section, the identity of manufacturing standards and requirements, as well as the similarity of other cost factors may well result in the two devices having substantially the same cost.

In addition, as has been indicated previously by this office, it would appear that the purpose of the "two device" requirement is not to prevent monopolization but to encourage research. Memorandum to D. A. Jensen, Executive Officer, Motor Vehicle Pollution Control Board, March 9, 196r. At the time this legislation was being considered, some forty-four devices were in various stages of development.

It was argued that the general public could be adequately protected without the requirement that there be two certified devices before installation became compulsory. The opponents of this requirement urged that if the use of the Salk vaccine had been deterred until such time as a competing vaccine were developed, many more children would have known the crippling effects of polio.

Ultimately the statute was amended to provide that if the Motor Vehicle Pollution Control Board found a device, the cost of which did not exceed \$65.00, the

\footnotetext{
${ }^{21}$ Ch. 200, $\S$ I, [1959] Cal. Stats. 209I, as amended, ch. 36, $\S$ I, [1960] Cal. Stats. 380, ch. 2031, 5 I [1965] Cal. Stats. 4607 (repealed rg67).

${ }^{12}$ Ch. 23, 1 , [r960] Cal. Stats. 348 (repealed I967); Opinion No. 64-304, 45 Op. Cat. ATr'Y Ges. 79 (1965). The schedule at which the device would be installed was set forth in scctions 24391 to 24398 of the Health and Safety Code. Ch. 23, $\$$ I, [1960] Cal. Stats. 349 (repealed 1967).

${ }^{13}$ Opinion No. 64-304, 45 OP. CaL. ATt'y GeN. 79, 80 (I965).
} 
maintenance of which would not exceed $\$ 15.00$ per year, and the life of which would not be less than 50,000 miles, then the Board could certify the device. Further, if the company holding the patent for such a device would license other companies to manufacturer the same, the installation would become mandatory according to the time schedule originally provided in the statute. ${ }^{14}$

\section{Permissibility of Delegation}

It may be argued that the legislative scheme outlined above improperly delegates legislative authority to the Director of Public Health and the Motor Vehicle Pollution Control Board. Since the same attack might be launched against the state and federal programs as they now exist, this seems the proper place to discuss whether the current pollution control problems violate prohibitions against the delegation of legislative authority. California has long recognized the permissibility of delegating administrative functions to boards and commissions. ${ }^{15}$ The legislature is not required to make detailed determinations of the facts which bring legislative policy into operation. $^{16}$

In upholding administrative regulations the court has said: ${ }^{17}$

\footnotetext{
${ }^{16} \mathrm{Ch} .82, \S \mathrm{I},\left[\mathrm{Ig}_{96}\right] \mathrm{Cal}$. Stats, (repealed 1967 ). This provision has been replaced by Caz. Heslta \& SAFETY CODE $\$ 39090$ (West Supp. Ig67).

${ }^{15}$ In both Stanislaus County Dairymen's Protective Ass'n v. County of Stanislaus, $8 \mathrm{Cal} .2 \mathrm{~d}$ 378, 390, 65 P.2d 1305, 1310 (1937), and Leftridge v. City of Sacramento, 59 Cal. App. 2d 516, 523, 139 P.2d II2, II6 (I943), the courts quote with approval I T. Cooley, Constitutional Limitations 23 I-32 (8th ed. W. Carrington I927) as follows:

"Boards and commissions now play an important part in the administration of our laws. The great social and industrial evolution of the past century, and the many demands made upon our legislatures by the increasing complexity of human activities, have made essential the creation of these administrative bodies and the delegation to them of certain powers. Though legislative power cannot be delegated to boards and commissions, the legislature may delegate to them administrative functions in carrying out the purpose of a statute and various governmental powers for the more efficient administration of the laws."

${ }^{20}$ In Franchise Tax Bd. v. Superior Court, 36 Cal. 2d 538, 548, 225 P.2d 905, 9II (I950), the court quotes, as follows, from Yakus v. United States, 32I U.S. 4I4, 424-25 (1944), that it is not necessary that the Legislature

"find for itself every fact upon which it desires to base legislative action or that it make for itself detailed determinations which it has declared to be prerequisite to the application of the legislative policy to particular facts and circumstances. . . . The essentials of the legislative function are the determination of the legislative policy and its formulation and promulgation as a defined and binding rule of conduct. ... These essentials are preserved when ... [the legislative body] ... has specified the basic conditions of fact upon whose existence or occurrence, ascertained from relevant data by a designated administrative agency, it directs that its statutory command shall be effective."
}

The court also notes that it is irrelevant that the legislature might, itself, have enacted the regulations. Id. at 425 .

${ }^{17}$ California Employment Comm'n v. Butte County Rice Growers Ass'n, 25 Cal. 2d 624, 632, 154 P.2d 892, 895 (r944). Upholding an administrative regulation, in Nelson v. Dean, 27 Cal. 2d 873, 88r, I68 P.2d 12, 21 (r946), the court quotes as follows from First Indus. Loan Co. v. Daugherty, 26 Cal. 2d 545, 549, x59 P.2d 921, 923 (1945):

"To narrowly proseribe the rule-making power of the [board] . . . would be to overlook one of the fundamental purposes of the policy of delegation of powers and to deprive the Legislature and the people of the state of one of the major benefits thereof. The essentials of the legislative function are the determination and formulation of the legislative policy. Generally speaking, attain- 
Where the Legislature has by its enactments declared policies and fixed primary standards ... . there can be no question but that it may validly confer on administrative officers power to "fill up the details" by prescribing rules and regulations to promote the spirit and purpose of the legislation and its complete operation.

The reasons for the adoption of the Air Pollution Control $\mathrm{Act}^{18}$ are crystal clear; they are the elimination, or at least the reduction, of all air contaminants, visible or otherwise. This standard seems fully adequate under California law. ${ }^{10}$

Various cases have approved standards at least as flexible as those set forth in the Motor Vehicle Pollution Control Act:

- "Water furnished in sufficient quantity at one or more places on each floor" for use of tenants. ${ }^{20}$

- Electrical equipment "dangerous to life or property."21

- Illuminating oils "safe, pure and [which] afford a satisfactory light."22

- Rules and Regulations as will "preserve the forests [within the federal reserve] ... from destruction."23

- "[W]hen in the public interest it deems it necessary in order to protect the consumer against unreasonably high prices."24

- As the agency deems it to be "in the public interest" to so act. ${ }^{25}$

ment of the ends, including how and by what means they are to be achieved, may constitutionally be left in the hands of others. The Legislature may, after declaring a policy and fixing a primary standard, confer upon executive or administrative officers the 'power to fill up the details' by prescribing administrative rules and regulations to promote the purposes of the legislation and to carry it into effect, and provision by the Legislature that such rules and regulations shall have the force, effect, and sanction of law does not violate the constitutional inhibition against delegating the legislative function.

The court refers to a "primary standard." However, "[t] he standards laid down by the Legislature for administrative action need not be minutely defined, and it is sufficient if they can be found by implication from the general purposes of a statute and from the reasons which must have led to its adoption." Metropolitan Water Dist. v. Marquardt, 59 Cal. 2d 159, 176, 379 P.2d 28, 36, 28 Cal. Rptr. 724, 732 $(1963)$.

${ }^{18}$ Cal. Health and SAfety COde $\$ \S 24198-24382$ (West Supp. 1967).

${ }^{10}$ In Holloway v. Purcell, 35 Cal. $2 \mathrm{~d} 220,217$ P.2d 665, cert. denied, 340 U.S. 883 (1950), tho standard attacked was the authority of the highway commission to designate and construct freeways on "such terms and conditions as in its opinion will best subserve the public interest." The court held that this delegation of legislative power was valid.

In California State Auto. Ass'n Inter-Ins. Bureau v. Downey, 96 Cal. App. 2d 876, 902, 216 P.2d 882,899 (1950), the court recited some of the yardsticks which have been approved by the U.S. Supreme Court as follows:

- "Just and reasonable" rates for sales of natural gas.

- "Public interest, convenience, or necessity" in establishing rules and regulations under the Federal Communications Act.

- Prices yielding a "fair return" or the "fair value" of property.

- "Unfair methods of competition" distinct from offenses defined under the common law.

- "Just and reasonable" rates for services of commission men.

- "Fair and reasonable" rent for premises, with final determination in the courts.

${ }^{20}$ Health Dep't v. Rector, I45 N.Y. 32, 39 N.E. 833 (1895).

${ }^{21}$ Gaylord v. City of Pasadena, I75 Cal. 433, I66 P. 348 (1917) (municipal ordinance).

22 Red "C" Oil Mfg. Co. v. Board of Agriculture, 222 U.S. $3^{80}$ (Igr2).

2s United States v. Grimaud, 220 U.S. 506 (IgIr).

s4 Sunshine Anthracite Coal Co. v. Adkins, 310 U.S. 381 (I940).

${ }^{25}$ National Broadcasting Co. v. United States, 319 U.S. 190 (1943). 
In People v. Aaron Ferer \& Sons, ${ }^{26}$ three defendants demurred to the complaint, contending that the Air Pollution Control Act failed to provide sufficient legislative standards. Involved was Rule 57, Air Pollution Control District of Los Angeles County, which prohibits the burning of combustible refuse in any open fire in Los Angeles County. ${ }^{27}$ The demurrer was overruled, and the decision affirmed by the appellate department. ${ }^{28}$

In People v. Advance Furniture Manufacturing Co., ${ }^{29}$ Judge Vernon W. Hunt, in an excellent memorandum opinion, held that the Air Pollution Control Act provides "a standard which is adequate to guide the administrative determination." The fact that these cases are unreported does not detract from their authority."

In I965, the oil interests in the County of Los Angeles challenged the constitutionality of the rules and regulations of the Air Pollution Control District of the county. ${ }^{31}$ In its memorandum decision, the court rejected the challenge. ${ }^{32}$ The

\footnotetext{
${ }^{20}$ Criminal No. 55525, Municipal Court of Los Angeles Judicial District (Los Angeles County, Cal., 1957).

${ }^{97}$ Cal. Health \& Safety Code $\$ \S 24198$ to 24322 (West I967, Supp. Ig67) provides the statutory scheme giving the district power to enact such a rule.

${ }^{2 B}$ Criminal App. No. 358o, App. Dep't, Super. Ct. (Los Angeles, Cal., x957).

${ }^{\circ 0}$ Criminal No. 48582, Municipal Court of Los Angeles Judicial District (Los Angeles County, Cal., 1956).

${ }^{80}$ MacDonald v. MacDonald, 155 Cal. 665, 672, ro2 P. 927, $93^{\circ}$ (I909); In re Estate of Little, 23 Cal. App. 2d 40, 43 (I937).
}

In Swisher v. Brown, I57 Colo. 378, 388-89, 402 P.2d 621, 627 (1965), the court said:

"It is not necessary that the legislature supply specific formula for the guidance of the administrative agency in a field where flexibility and adaption of the legislative policy to infinitely variable conditions constitutes the essence of the program. The modern tendency is to permit liberal grants of discretion to administrative agencies in order to facilitate the administration of laws dealing with involved economic and governmental conditions. In other words, the necessities of modern legislation dealing with complex economic and social problems have led to judicial approval of broad standards for administrative action, especially in regulatory enactments under the police power. With respect to such types of legislation, detailed standards in precise and unvarying form would be unrealistic and more arbitrary than a general indefinite standard."

${ }^{31}$ G.W.A., Inc. v. Air Pollution Control Dist., Los Angeles, Cal., Super Ct. No. SC 836864 (Memorandum Opinion, Jan. 26, rg66).

82 The court stated:

"The Legislature cannot delegate its power to make a law, but for the proper enforcement of its laws it may make a law to delegate a power to determine some fact or state of things upon which the law makes or intends to make its own action depend. In re McLain, r9o Cal. 376, $379,38 \mathrm{I}$ [212 P.2d 620, 621-22 (I963)]. In the case of Marshall Field \& Company v. Clark, I43 U.S. $649,694[(1892)]$, the court in referring to whether a legislature could delegate such power stated:

"To deny this would be to stop the wheels of government. There are many things upon which wise and useful legislation must depend which cannot be known to the lawmaking power, and, must, therefore, be a subject of inquiry and determination outside of the halls of legislation.'

"In the case of United States $v$. Grimaud, 220 U.S. 506, 521 [19rr)], it is stated:

" 'But the authority to make administrative rules is not the delegation of legislative power, nor are such rules raised from an administrative to a legislative character because the violation thereof is punished as a public offense.'

"The Supreme Court of California as early as I9I7 in considering the delegation of administrative power by the legislative body of a city to a city official in the case of Gaylord $\nu$. City of Pasadena, I75 Cal. 433, 436 [I66 P. 348, 349 (I9I7)] stated:

" "Even a casual observer of governmental growth and development must have observed the 
plaintiffs appealed, but then abandoned the appeal in January rg68. It would appear, therefore, that neither the Motor Vehicle Pollution Control Act nor its successor statute $^{33}$ violate the prohibition against the delegation of legislative authority.

\section{Areas in Which Installation of the Device Would Not Be \\ Required Even After Certification}

The history of air pollution legislation in California indicates a recognition that effects of air pollution will differ considerably, depending on such factors as topography, meteorology, and population density. Therefore, in those areas in which air pollution would not (at least initially) present a serious problem, the boards of supervisors of the various counties in California could determine that it was unnecessary for the preservation of air quality in the county to implement the air pollution control measures set forth either by the legislature or the Board of Motor Vehicle Pollution Control. ${ }^{34}$

\section{E. Recapitulation of Statutory Scheme Prior to the Enactment of 1967 Legislation}

Prior to enactment of Ig6y legislation, the California statutory system embodied these assumptions:

I. Air pollution problems differ in intensity (and indeed in some areas are almost non-existent).

2. It is necessary to delegate the responsibility for deriving maximum levels of air pollution emanating from automobiles to some administrative agency possessing an expertise in medical and/or scientific research.

3. It would be necessary to delegate to an administrative agency possessing an expertise in engineering and/or scientific research the responsibility for testing (or having tested) and certifying proposed motor vehicle pollution control devices.

4. The public should be protected against the possibility of an undue economic burden which might emanate from monopolies in the field of motor vehicle pollution control devices.

5. The board of supervisors of each county should be given the power to determine whether the provisions of the motor vehicle pollution control legislation were

ever-increasing multiplicity and complexity of administrative affairs-natural, state, and municipal -and even the occasional reader of the law must have perceived that from necessity, if for not better grounded reason, it has become increasingly imperative that many quasi-legislative and quasijudicial functions, which in smaller communities and under more primitive conditions, were performed directly by the legislative or judicial branches of the government, are intrusted to departments, boards, commissions, and agents. No sound objection can any longer be successfully advanced Id. to this growing method of transacting public business." "

${ }^{83}$ Cal. Health \& SAFety Code $\$ \$ 39080$ to 39098 (West Supp. 1967), discussed 305-06 infra.

${ }^{84}$ Cal. Health \& SAFETy CODE $\$ 39090(k)$ (West Supp. 1967). The efficacy of a state statute within a given area may be made to depend upon the action of some political subdivision of the state. E.g., Housing Authority v. Dockweiler, I4 Cal. 2d 423, 446, 94 P.2d 794, 799-800 (I939); Hunter v. Adams, I80 Cal. App. 2d 5rI, 4 Cal. Rptr. 776 (1960). 
necessary to preserve the air quality standards recommended by the director of public health.

6. In those areas of the state of California in which local agencies determine that control was necessary for the preservation of air quality, uniform standards should exist.

7. Failure to install a certified device is a misdemeanor; and any alteration of the device which reduces its efficiency is also a misdemeanor. ${ }^{35}$

II

\section{The Statutory Scheme Under the I967 Legislation}

In I967 the California Legislature adopted the Mulford-Carrell Air Resources Act. $^{36}$ Many of the earlier legal provisions, heretofore discussed, have been incorporated in the 1967 legislation. The major differences are as follows:

I. The director of public health recommends certain standards of air quality to the Air Resources Board.

2. The Air Resources Board is empowered to: (a) divide the state into basins; (b) adopt standards of air quality which may vary from basin to basin; (c) adopt standards for the emissions of motor vehicles; (d) adopt rules and regulations as required to effectuate the purposes of the act; $; 3$ and (e) test and approve motor vehicle pollution control devices. ${ }^{38}$

3. In order to be exempted from the requirement that a certified device be installed on the motor vehicle there must not only be a finding by the board of supervisors in the county in which the motor vehicle is registered that the installation of such device is not necessary within that county for the preservation of air quality within that county, but apparently a similar finding with reference to the adjacent counties must be made by the respective boards of supervisors. ${ }^{39}$

Section 39087 of the California Health \& Safety Code provides:

Whenever the board issues certificates of approval for two or more devices for the control of emissions of pollutants from a particular source of emissions from motor vehicles for which standards have been set by the board, it shall so notify the Department of Motor Vehicles.

This section appears to have no place in the 1967 legislation, but is rather a vestigial appendage, the usefulness of which ceased to exist when the legislature decided that

\footnotetext{
${ }^{85}$ CAL. Ventele CODE $\$ 27156$ (West Supp. 1967). It would appear that in order to enforce this section testing devices or a system of test facilities would have to be provided. See Cal. Vemicte CODE $\$ \$$ 4000-4000.I (West Supp. 1967).

${ }^{80}$ Cal. Health \& Safety Code $\$ \$ 39000$ to 39570 (West Supp. I967).

${ }^{87}$ Cal. Health Code $\$ \$ 3905$ I (a)-(d) (West Supp. 1967).

${ }^{38}$ CaL. Health \& SAFETY Code $\$ \$ 39080$ to 39098 (West Supp. I967). It should be noted that $\$ 39083$ (d) (2) refers to $\$ 426.5$ of the Health and Safety Code. Since $\$ 426.5$ has been repealed, it would appear that the legislature intended to refer to the standards promulgated by the Air Resources Board.

"See Cal. Health \& SAfety Code $\$ 39090(k)$ (West Supp. 1967).
} 
the general public could be adequately protected without requiring two certtied devices prior to compulsory installation. The section would probably be interpreted to require the Air Resources Board to notify the Department of Motor Vehicles whenever a device was certified and the manufacturer agreed to license others to manufacture it. ${ }^{40}$

\section{III}

\section{The State Legislature Has Preempted the Field to the Exclusion of Actions bx Local Governmental Bodies}

\section{A. Legal Foundation of Regulating Air Contamination}

The power to regulate smoke, smog, and atmospheric pollution is generally found within the police power of the governmental agency. In some instances, there is a specific power, granted under charter or statute, to adopt reasonable regulations to protect the public health, safety, and welfare.

The term "police power" is very broad and does not lend itself to any practical definition. It is a dynamic term subject to change and evolution as a commonwealth develops politically, economically, and socially. ${ }^{41}$ It is a power of sovereignty inherent in a state and possessed by each of them. The police power of a municipality is never inherent but is a "delegated power" received by delegation from a higher source by constitutional, statutory, or charter provision. ${ }^{42}$ The mode of delegation of the power ordinarily is not important, if it is in fact delegated. ${ }^{43}$

The police power delegated to cities and counties is not all-embracing, however, in that the state may take such power unto itself by direct enactment or by occupying the field. ${ }^{44}$

It is the general rule that there cannot be a conflict between local ordinances and the state law, unless the state law itself allows the difference. ${ }^{45}$ Under this rule an ordinance ordinarily cannot permit that which the statute forbids, or prohibit that

\footnotetext{
${ }^{10}$ See Cal. Hearth \& Safety Code $\$ 39085$ (West Supp. 1967).

${ }^{41}$ Miller v. Board of Pub. Works, I95 Cal. 477, 484-85, 234 P. 38r, 383-84 (x925).

${ }^{12}$ See, e.g., Leighton v. City of Minneapolis, I6 F. Supp. Ior (D. Minn. 1936); Denninger v. Recorder's Court, 145 Cal. 629, 79 P. 360 (1904); Commonwealth v. Plaisted, 148 Mass. 375, 19 N.E. 224 (ז889).

${ }^{3}$ See, e.g., People v. City of Chicago, 4 I3 Ill. 83, 108 N.E.2d 16 (1952); City of Wichita Falls v. Continental Oil Co., II7 Tex. 256, I S.W.2d 596 (I928).

"In re Iverson, I90 Cal. 582, 250 P. 68I (I926).

In Roussey v. City of Burlingame, 100 Cal. App. 2d 321, 324, 223 P.2d 517, 519 (1950), the court, in considering the municipal police power granted by general constitutional provisions, stated:

"It is a power that may not be unreasonably invoked and applied. It is not illimitable. The marking and measuring of the extent of its exercise and application is determined by a consideration of the question whether or not the invocation of the power, in any given case and as applied to existing conditions, is reasonably necessary to promote the public health, safety, morals or general welfare of the community."

${ }^{45}$ See, e.g., In re Hoffman, I55 Cal. 114 , 99 P. 517 (1909); State v. Dannenberg, 150 N.C. 799, 63 S.E. 946 (rgog).
} 
which a statute in effect directs to be permitted. Ordinances may ordinarily add 2dditional restrictions to those established by state law. ${ }^{46}$ In some states, ordinances which prohibit the same acts as the state statutes are invalid. The most common theory for so holding is that to allow both to stand would result in double jeopardy. ${ }^{47}$

B. A Consideration of the State Statutes in the Area

The Supreme Court of California has set forth these guidelines as to whether the state has preempted a particular segment of the police power: ${ }^{48}$

Analysis of the many prior decisions on this subject indicates that although the language differs from case to case, the rationale of all have one thing in common, that is, that the chartered counties and cities have full power to legislate in regard to municipal affairs unless: $(\mathrm{I}$ ) the subject matter has been so fully and completely covered by general law as to clearly indicate that it has become exclusively a matter of state concern; (2) the subject matter has been partially covered by general law couched in such terms as to indicate clearly that a paramount state concern will not tolerate further or additional local action; or (3) the subject matter has been partially covered by general law, and the subject is of such a nature that the adverse effect of a local ordinance on the transient citizens of the state outweighs the possible benefit to the municipality.

Applying any of these three tests, it is apparent that the state has, in fact, occupied the field:

(r) The subject matter has been fully and completely covered by general law, since the act contains a comprehensive scheme for the control of pollutants emanating from motor vehicle exhaust. ${ }^{49}$

(2) Legislation has been couched in such terms as to clearly indicate that a paramount state concern will not tolerate further or additional local action..$^{50}$

(3) There has been legislation on a state level and local ordinances would only serve to confuse the transient citizen. The population of California is an extremely mobile one. (There are one and one-half cars per family in Los Angeles County.) Further, the population often crosses city and county lines in traveling to jobs and to recreation areas, for example. If those utilizing the automobile as a prime method

\footnotetext{
${ }^{40}$ E.g., Borok v. City of Birmingham, I9I Ala. 75,67 So. 389 (19I4); Sternall v. Strand, 76 Cal. App. 2d 432, I72 P.2d 92x (1946).

${ }^{47}$ E.g., State v. Welch, 36 Conn. 215 (I869).

${ }^{48}$ In re Hubbard, 62 Cal. 2d 119, 128, 396 P.2d 809, 814-15, 41 Cal. Rptr. 393, 398-99 (1964). (Emphasis added.)

${ }^{\text {} 0}$ Cal. Health \& Safety Code $\$ \S 39080$ to 39098 (West Supp. 1967).

50 "Local and regional authorities have the primary responsibility for the control of air pollution except for the emissions from motor vehicles. These authorities may control cmissions from nonvehicular sources. . ." CaL. Heatth \& SAfETY Code $\$ 39012$ (West Supp. 1967). (Emphasis added.)

"The Legislature finds and declares:

"(c) That the state has a responsibility to establish uniform procedures for compliance with standards which control or eliminate such pollutants [i.e., pollutants emanating from motor vehicles]."

CaL. Health \& SAfEty CODE $\$ 39080$ (c) (West Supp. r967). (Emphasis added.)
} 
of transportation were to be subjected to a myriad of city and county regulations governing air pollution emanating from the automobile, hopeless confusion would result. Therefore, the state has clearly preempted any local regulation in the field of motor vehicle pollution.

Moreover, if local air pollution control districts ever had the power to issue regulations to control motor vehicle pollution, ${ }^{51}$ that power has been impliedly revoked by subsequent legislation.

\section{Indirect Motor Vehicle Pollution Control Through Contract}

As indicated above, California has preempted the field of motor vehicle pollution control to the exclusion of enactments by local governmental agencies. However, these same agencies might, through contract, exercise some indirect control. The County of Los Angeles did so by providing in orders of the county board of supervisors that no motor vehicle would be purchased by the county unless the emissions emanating from the vehicle met certain standards set forth in the board order. ${ }^{62}$ Senate Bill 77 of the I968 California Legislative Session provides for similar standards with respect to state-owned vehicles.

We believe that despite the preemption by the state with respect to activities by local governmental agencies in this particular area, the county could, by contract, impose these requirements. Similarly, the state could impose more stringent standards through the utilization of contract conditions. ${ }^{53}$

\footnotetext{
${ }^{51}$ See Cal. Health \& Safety Code $\$ \$ 24198$ to 24341 (West Supp. 1967).

${ }^{5}$ Board Order No. 155, Board of Supervisors for Los Angeles County, Nov, 19, 1963. See also the following orders of the Board of Supervisors: Board Order No. $x_{7}$, Dec. 5, x963; Board Order No. 18r, Dec. 12, 1967; Board Order No. 181, Jan. 12, 1968.

${ }^{58}$ This would be possible even if the federal government has preempted the field. Federal preemption is discussed at pp. 312-14 infra.

In the case of Interstate Consol. St. Ry. v. Massachusetts, 207 U.S. 79 (xg07), a corporation had been incorporated by a statute providing that the corporation must comply with all existing statutes. In holding that the corporation could not attack the constitutionality of the statute requiring public carriers (of which the corporation was one) to carry school children at a reduced fare, Justice Holmes said:

"If the charter, instead of writing out the requirements of Rev. L. 112, \$72, referred specifically to another document expressing them, and purported to incorporate it, of course the charter would have the same effect as if it itself contained the words. If the document was identified, it would not matter what its own nature or effect might be, as the force given to it by reference and incorporation would be derived wholly from the charter. The document, therefore, might as well be an unconstitutional as a constitutional law. . . . But the contents of a document may be incorporated or adopted as well by generic as by specific reference, if only the purport of the adopting statute is clear."

Id. at $84-85$.

In Strange v. City of Cleveland, 94 Ohio St. $377,381-82$, II 4 N.E. 261,263 (1916), the court held as follows:

"The contract itself contained the following provision: 'The contractor agrees that he will comply with the provisions of the labor laws of the City of Clereland and the State of Ohio, particularly as outlined in Section r 96 of the City Charter.'
}

- •.

“.. [I]n this case by the terms of the contract itself the parties thereto specifically bound 


\section{Federal Legislation}

\section{A. Legislative History Prior to 1967}

In I954 we urged the Congress to adopt legislation in the field of motor vehicle pollution control and argued that the federal government should compel automobile manufacturers to install exhaust control devices as part of the necessary equipment on new automobiles. ${ }^{54}$

Since the great bulk of the automobiles produced in this country are destined for interstate commerce or travel at one time or another, it is obvious that Congress has the authority to enact such legislation pursuant to its power to "regulate Commerce ... among the several States."55

The argument against such a federal requirement is that a rancher in a remote area of Wyoming or Montana would have little if any need for an expensive exhaust control device. As a rejoinder, however, it was urged that the vehicle belonging to the rancher may later be owned by a factory worker in Los Angeles-such is the mobility of our society and of a motor vehicle.

In I $_{65}$ Congress amended the Clean Air Act. ${ }^{56}$ This was the first federal legislation that, when implemented, would require the installation of air pollution control devices which would meet the standards set forth by the Department of Health, Education, and Welfare.

The 1965 Clean Air Act amendments did not contain any specific language with respect to the intention of Congress to preempt the field of motor vehicle pollution control. Moreover, the legislative history of the 1965 act would lead one to believe that it was the intention of the legislature to preempt the field of motor vehicle pollution control with respect to new motor vehicles. ${ }^{\mathbf{5 7}}$

themselves to observe the regulations covered by the ordinance complained of. Plaintiff in error does not present a situation which avoids the enforcement of the ordinance."

"Hearings on the Housing Act of 1954, Air Pollution Prevention Amendment, Before the Senate Comm. on Banking and Currency, 83d Cong., 2d Sess., pt. 2, at 1205 (1954) (statement of Harold W. Kennedy). See also Hearings on Water and Air Pollution Control Before the Subcomm. on Flood Control-Rivers and Harbors of the Senate Comm. on Public Works, 84th Cong., Ist Sess. 257 (1955) (statement of Harold W. Kennedy).

${ }^{85}$ U.S. CoNsT. art. I, \& 8, cl. 3 .

so \$ ror, 79 Stat. 992 (1965).

${ }^{57}$ See H.R. REP. No. 728, 9 oth Cong., Ist Sess. 20-2I ( 1967$)$ :

"Public Law 89-272, enacted October 20, I965, authorized the Secretary of Health, Education, and Welfare to establish national standards applicable to emissions from new motor vehicles and new motor vehicle engines. That legislation contains no explicit statement concerning the preemption of State laws on this subject, and no statements concerning this problem were made on either the House or the Senate floor when the bill was debated.

"The report of this committee on the bill (H. Rept. 899, 89th Cong.) contains the following statement: "The committee is convinced that motor vehicle exhaust control standards on a national seale are necessary and would be of benefit to the entire country. . . . While the committee is cognizant of the basic rights and responsibilities of the States for control of air pollution, it is apparent that the establishment of Federal standards applicable to motor vehicle emissions is preferable to regulation by individual States.' 


\section{B. The Air Quality Act of 1967}

The Air Quality Act of $1967^{\overline{5}}$ is almost a complete recodification of the Clean Air Act except that the 1967 act specifically sets forth the intention of the Congress to preempt the field of motor vehicle pollution control. Section 208 provides: ${ }^{59}$

Sxc. 208. (a) No State or any political subdivision thereof shall adopt or attempt to enforce any standard relating to the control of emissions from new motor vehicles or new motor vehicle engines subject to this title. No State shall require certification, inspection, or any other approval relating to the control of emission from any new motor vehicle or new motor vehicle engine as condition precedent to the initial retail sale, titling (if any), or registration of such motor vehicle, motor vehicle engine, or equipment.

(b) The Secretary shall, after notice and opportunity for public hearing, waive application of this section to any State which has adopted standards (other than crankcase emission standards) for the control of emissions from new motor vehicles or new motor vehicle engines prior to March 30, I966, unless he finds that such State does not require standards more stringent than applicable Federal standards to meet compelling and extraordinary conditions or that such State standards and accompanying enforcement procedures are not consistent with section 202(a) of this title.

(c) Nothing in this title shall preclude or deny to any State or political subdivision thereof the right otherwise to control, regulate, or restrict the use, operation, or movement of registered or licensed motor vehicles.

Section 202 provides in part: $:^{e 0}$

SEC. 202. (a) The Secretary shall by regulation, giving appropriate consideration to technological feasibility and economic costs, prescribe as soon as practicable standards, applicable to the emission of any kind of substance from any class or classes of new motor vehicles or new motor vehicle engines, which in his judgment cause or contribute to, or are likely to cause or contribute to, air pollution which

"The report of the Senate committee on the bill (S. Rept. 192, 89th Cong.) contains the following two statements: 'In view of the fact that the automobile is one of the principal sources of air pollution and manufacturers have the capability of incorporating air pollution reduction facilities in their vehicles, there is no apparent reason why the entire Nation should not benefit from such advances. Also, it would be more desirable to have national standards rather than for each State to have a variation in standards and requirements which could result in chaos insofar as manufacturers, dealers, and users are concerned[.]' (p. 6). 'The committec has found that the automative industry has the capability for limiting the emissions of hydrocarbons and carbon monoxide from both the crankcase and exhaust systems of gasoline powered motor vehicles and found a willingness to accept legislation which would establish national standards, and it is the hope of the committee that individual States will accept national standards rather than additionally impose restrictions which might cause undue and unnecessary expense to the user.' (P. 8.)

"Since the enactment of Public Law 89-272, the Secretary of Health, Education, and Welfare has established national standards applicable to emissions from new motor vehicles for the 1968 and subsequent model years. [45 C.F.R. $\$ \$ 85 . \mathrm{r}-.87$ ( 1967$)$.] The Congress is therefore presented directly with the question of the extent to which the Federal standards should supersede State and local laws on emissions from motor vehicles."

(Emphasis added.)

${ }^{58} 8$ I Stat. 485 .

${ }^{60} 81$ Stat. 485.

${ }^{\circ 0} 8$ I Stat. 499 (I967). 
endangers the health or welfare of any persons, and such standards shall apply to such vehicles or engines whether they are designed as complete systems or incorporate other devices to prevent or control such pollution.

Section 208, as originally proposed, stated in essence that the federal government preempts the area of motor vehicle pollution control unless California could show some immediate and peculiar problem which could not be adequately assuaged by the implementation of national standards. Thus, the burden was upon California to demonstrate that state standards were, in fact, necessary if the health and welfare of its inhabitants were to be preserved.

After a long and bitter battle, the section was reworded as indicated above to place the burden upon those who allege that the national standards are, in fact, adequate for California. Section 208 does not specifically refer to California; however, House Report 728 provides: ${ }^{61}$

In other words, as passed by the Senate, section 208(b) provides for a waiver of preemption in the case of California, so that California could be permitted to establish (I) more stringent standards applicable to emissions control than federal standards, (2) standards applicable to emissions not covered by federal standards, and (3) enforcement procedures and standards with respect to emissions differing from Federal enforcement procedures and standard[s].

On July II, Ig68, after public hearings in San Francisco and Los Angeles, the Secretary found (I) that California requires standards more stringent than the applicable federal standards, and (2) that California has such standards. Therefore, in accordance with section $208(\mathrm{~b})$, the Secretary waived the application of section 208(a) to certain provisions of the California Administrative Code. ${ }^{\text {61a }}$

It should be noted, however, that if, after a hearing, the Secretary determines that it is unnecessary for the preservation of the health and welfare of the citizens of California to allow said state to adopt additional or more stringent regulations, then California will be precluded from doing so. Furthermore, if, after hearing, the Secretary determines that the implementation of the California standards is not technologically or economically feasible, then California would also be precluded from implementing state standards.

On January 30, I967, President Johnson requested the adoption of an Air Quality Act which would include provisions for state inspection of air pollution control devices. He proposed that such an inspection system be on a matching grant basis. ${ }^{62}$ Section 209 of the Air Quality Act of 1967 provides: ${ }^{.3}$

\footnotetext{
${ }^{01}$ H.R. Rep. No. 728, 90th Cong., Ist Sess. 21 ( 1967 ).

${ }^{01 a} 33$ Fed. Reg. Ior60 (I968). Applicability of $\$ 208$ (a) was waived for I3 CAL. AD. CODE \$\$ I925, I935 (exhaust standards for I969 model gasoline powered motor vehicles); $\$$ I950 (fuel evaporative standards for model 1970 gasoline powered motor vehicles); and $\$$ 2100, 2102, 2105, 2108, 2109, 2500, 2502, $2504,2507,2508$ (certification of control devices and test procedures). The waiver is applicable only for those model years specified.

-2 President of the Untted States, Message on Arr Pollution, H.R. Doc. No. 47, 90th Cong., Ist Sess. 4 (1967).

${ }^{68} 8 \mathrm{r}$ Stat. 502.
} 
The Secretary is authorized to make grants to appropriate State air pollution control agencies in an amount up to two-thirds of the cost of developing meaningful uniform motor vehicle emission device inspection and emission testing programs except that ( $\mathrm{I}$ ) no grant shall be made for any part of any State vehicle inspection program which does not directly relate to the cost of the air pollution control aspects of such a program; and (2) no such grant shall be made unless the Secretary of Transportation has certified to the Secretary that such program is consistent with any highway safety program developed pursuant to section 402 of title 23 of the United States Code.

\section{Power of Preemption by the Federal Government of the Regulation of Pollution Emanating from Automobiles}

In our earlier discussion we indicated that the federal government intended to preempt the field of air pollution emanating from new automobiles, beginning with the model year I968. The United States Constitution provides that Congress shall have the power to "regulate Commerce with foreign Nations, and among the several States." ${ }^{\text {"64 }}$ Congress has found that with respect to the control of air pollution emanating from new automobiles beginning with the model year Ig68 such control must of necessity be uniform and national in character. When the subject is national in its character, or of such a nature as to allow only a uniform system of regulation, any state law in the field will fall. ${ }^{65}$

It would, therefore, appear that no state, with the possible exception of Cali-

${ }^{\circ}$ U.S. Const. art. I, $\$ 8$, cl. 3. Chief Justice Marshall, in Gibbons v. Ogden, 22 U.S. (9 Wheat.) I, 189-90 (1824), stated: "Commerce, undoubtedly, is traffic, but it is something more it is intercourse. It deseribes the commercial intercourse between nations, and parts of nations, in all its branches, and is regulated by prescribing rules for carrying on that intercourse." In that case, the state of New York had granted to Robert Fulton the exclusive right to operate steam boats in the waters of the state. In examining the "collision" between state and federal law, Marshall concluded: "In one case and the other, the acts of New York must yield to the law of Congress; and the decision sustaining the privilege they confer, against the right given by a law of the Union, must be erroneous." Id. at 2ro.

In the case of Liesy v. Hardin, I35 U.S. 100, 108 (1890), Mr. Chief Tustice Fuller stated:

"The power vested in Congress 'to regulate commerce with forcign nations, and among the several States, and with the Indian tribes,' is the power to prescribe the rule by which that commerce is to be governed, and is a power complete in itself, acknowledging no limitations other than those prescribed in the Constitution. It is co-extensive with the subject on which it acts and cannot be stopped at the external boundary of a State, but must enter is interior and must be capable of authorizing the disposition of those articles which it introduces, so that they may become mingled with the common mass of property within the territory entered. . . .

". . . The power to regulate commerce among the States is a unit, but if particular subjects within its operation do not require the applieation of a general or uniform system, the States may legislate in regard to them with a view to local needs and circumstances, until Congress otherwise directs ...."

(Emphasis added.)

In Pennsylvania v. Wheeling \& Belmont Bridge Co., 54 U.S. (13 How.) 518 (1851), the state of Virginia had authorized the construction of a bridge on the Ohio River. Congress had acted to regulate navigation upon the river. In holding that the bridge was an unlawful obstruction to navigation, the Court stated: "No State law can hinder or obstruct the free use of a license granted under an act of Congress." Id. at 566 .

${ }^{\circ 5}$ Southern Pac. Co. v. Arizona, 325 U.S. 76I (1945); Welton v. Missouri, 9I U.S. 275 (1875); Cooley v. Board of Wardens, 53 U.S. (I2 How.) 299 (185r). 
fornia, could prohibit the sale of motor vehicles beginning with the model year I968 even though said vehicles might not comply with air pollution standards which had been established by that state. It would also appear that a state air pollution control certificate could not be required as a condition for the use of said vehicles, except possibly in California, because this would be an attempt to do by indirection that which the state could not do directly. To hold otherwise would be to allow the state to thwart the rational and uniform plan for air pollution control promulgated by the federal government. Nothing in the Air Quality Act indicates an intention by the federal government to regulate vehicles manufactured prior to model year 1968. There is no constitutional rule that Congress must occupy the whole field. $^{66}$

In fields in which the state and federal governments have purported to deal with the same subjects for the same purposes, the Supreme Court has relied on a number of tests to determine whether or not state regulation has been superseded by federal control. In Pennsyluania $v$. Nelson, ${ }^{67}$ the Court delineated the following tests:

I. Is the scheme of federal regulation so pervasive as to make reasonable the inference that Congress left no room for states to supplement it?

2. Does the federal statute touch a field in which the federal interest is so dominant that the federal system must be assumed to preclude enforcement of state laws on the same subject?

3. Would enforcement of the state statute present a serious danger of conflict with administration of the federal program?

We believe that the answers to all three questions with reference to the control of pollution emanating from used motor vehicles must be answered in the negative. In the case of Florida Lime \& Avocado Growers, Inc. v. Paul, ${ }^{68}$ the Supreme Court refused to strike down a California statute which, in effect, excluded from the state of California certain Florida avocados which met federal standards for maturity. The Court said: "Congressional regulation of one end of the stream of commerce does not, ipso facto, oust all state regulation at the other end."'09

Therefore, we conclude that the "field" of prescribing the air pollution control devices which must be installed on motor vehicles manufactured prior to the model year I 968 has been left by the federal government to the states; the states may prescribe

\footnotetext{
${ }^{00}$ See Kelly v. Washington, 302 U.S. I (I937). State laws have been upheld in the following cases, despite extensive congressional action in the field: Huron Portland Cement Co. v. City of Detroit, 362 U.S. 440 ( 1960 ) (air pollution from ships); Kelly v. Washington, 302 U.S. I (I937) (safety inspection of tugs); Mintz v. Baldwin, 289 U.S. 346 (I933) (diseased cattle); Atchison T. \& S.F. Ry. v. Railroad Comm'n, 283 U.S. 380 (I93I) (union passenger stations); Savage v. Jones, 225 U.S. 501 (Igr2) (branding of foods).

${ }^{\circ 7} 350$ U.S. $497,502,504-05$ (1956).

${ }^{08} 373$ U.S. I32 (rg62).

${ }^{00} \mathrm{Id}$. at I45. It would appear that if the regulation takes place after production has been completed for the purpose of imposing higher state standards, the regulation will be upheld. Cf. Cloverleaf Butter Co. v. Patterson, 315 U.S. I48 (I942); McDermott v. Wisconsin, 228 U.S. II5 (I9I3).
} 
such rules and regulations as are reasonably necessary to protect or promote the health and safety of their inhabitants.

\section{Conclusion}

Many automobiles currently operating on the highways of the several states within the United States were manufactured prior to model year 1968 . These automobiles will continue to function for a great many years. The state of California has adopted a system of legislation which is presently designed primarily to devise methods by which air pollution from these automobiles may be controlled. The California Legislature has not been unmindful of the costs to the operator of the motor vehicle of such a pollution control program.

At the present time, the California standards for emissions for automobiles manufactured, beginning with the model year I968, are no more stringent than the federal government's standards. ${ }^{70}$ It would appear that in deriving the standards, the Department of Health, Education, and Welfare took the standards for various pollutants recommended by the individual states, and combined them to establish a national standard.

California has proposed new standards which will be applicable to all motor vehicles registered in the state. These standards are more stringent than those which have, as of this date, been promulgated by the Department of Health, Education, and Welfare. As already noted, the preemption of these standards by federal law has recently been waived for 1969 and 1970 model-year vehicles. ${ }^{71}$ It may well be that the ever-increasing population growth and urbanization will one day dictate even greater and more stringent regulations, both on the state and national level, but at least we have begun to deal with the dynamic health problems associated with air pollution emanating from motor vehicles.

\footnotetext{
${ }^{10}$ Compare the standards set forth in CAL. AD. CODE tit. 17, $\$ 30500-30520$ (I961 as augmented in 1966), with the federal regulations contained in 45 C.F.R. $\$ \$ 85.1-87$ (I967).

${ }^{71} 33$ Fed. Reg. I0160 (1968). See note 6ra supra.
} 